\title{
Extended hepatic metastasectomy for renal cell carcinoma-new aspects in times of targeted therapy: a single-center experience over three decades
}

\author{
Oliver Beetz ${ }^{1} \cdot$ Rabea Söffker ${ }^{1} \cdot$ Sebastian Cammann ${ }^{1} \cdot$ Felix Oldhafer $^{1} \cdot$ Florian W. R. Vondran $^{1} \cdot$ Florian Imkamp $^{2}$. \\ Jürgen Klempnauer ${ }^{1} \cdot$ Moritz Kleine ${ }^{1}$ (i)
}

Received: 16 September 2019 / Accepted: 29 December 2019 / Published online: 14 January 2020

(C) The Author(s) 2020

\begin{abstract}
Purpose Despite the introduction of novel targeted therapies on patients with renal cell carcinoma, syn- and metachronous metastases (including hepatic lesions) are observed frequently and significantly influence patient survival. With introduction of targeted therapies as an effective alternative to surgery, therapeutical strategies in stage IV disease must be reevaluated.

Methods This is a retrospective analysis of 40 patients undergoing hepatic resection of histologically confirmed RCC metastases at our institution between April 1993 and April 2017.

Results The interval between nephrectomy for renal cell carcinoma and hepatic metastasectomy was 44.0 months (3.3-278.5). Liver resections of different extents were performed, including multivisceral resections. The median follow-up was 37.8 months (0.5-286.5). Tumor recurrence after resection of hepatic metastases occurred in 19 patients resulting in a median disease-free survival of 16.2 months (0.7-265.1) and a median overall survival of 37.8 months (0.5-286.5). Multivariable analysis identified multivisceral resection as an independent risk factor for disease-free and overall survival ( $p=0.043$ and $p=0.001$, respectively). A longer interval between nephrectomy and hepatic metastasectomy was identified as an independent significant protective factor for overall survival $(p<0.001)$. Patients undergoing metastasectomy after introduction of sunitinib in Europe in $2006(n=15)$ showed a significantly longer overall survival (45.2 (9.1-111.0) versus $27.5(0.5-286.52)$ months in the preceding era; $p=0.038)$.

Conclusion Hepatic metastasectomy, including major and extended resections, on patients with metastasized renal cell carcinoma can be performed safely and may facilitate long-term survival. Due to significant morbidity and increased mortality, multivisceral resections must be weighed against other options, such as targeted therapy.
\end{abstract}

Keywords Renal cell carcinoma $\cdot$ Non-colorectal liver metastases $\cdot$ Hepatic metastasectomy $\cdot$ Extended surgery

\section{Introduction}

Renal cell carcinoma (RCC) is a malignant disease with increasing incidence, ranging from 3 to 12 cases per 100,000 people in Europe and Northern America.

Electronic supplementary material The online version of this article (https://doi.org/10.1007/s00423-019-01852-4) contains supplementary material, which is available to authorized users.

Moritz Kleine

Kleine.Moritz@mh-hannover.de

1 Department of General, Visceral and Transplant Surgery, Hannover Medical School, Carl-Neuberg-Strasse 1, 30625 Hannover, Germany

2 Clinic for Urology and Urologic Oncology, Hannover Medical School, Carl-Neuberg-Strasse 1, 30625 Hannover, Germany
Despite entering the era of novel targeted therapies such as tyrosine kinase inhibitors, mortality rates are still at more than 2.4 per 100,000 people in many Western countries [1]. This is partially owed to the fact that around $30 \%$ of the patients initially present themselves with synchronous distant metastases, whereas another $30 \%$ suffer from metachronous metastases after nephrectomy in curative intent [2]. Although bone and lung lesions are most frequently observed in cases of metastatic disease, the liver is involved in $20 \%$ of the patients [3]. Studies in the past have analyzed the influence of metastasectomy in general on the disease-free and diseasespecific survival and showed beneficial effects for surgical resection in selected patients $[4,5]$.

The role of hepatic resection is still a matter of debate: Grimes, Pikoulis, and Pinotti each published reviews on this issue with patient series ranging from 4 to 85 patients [6-8]. 
However, patients with RCC liver metastases are often included in reports on resection of non-colorectal and non-endocrine liver metastases, limiting the significance of drawn conclusions. Furthermore, none of the studies present significant patient numbers after introduction of targeted therapy.

Several scores have been provided in the past to estimate the prognosis of patients in a metastatic stadium (stadium IV) of RCC. The Memorial Sloan-Kettering Prognostic Factors Model, which was introduced by Motzer et al. in 1999 and modified by Mekhail et al. in 2005, is currently the most widely accepted and validated model for larger patient series [9-11].

The objective of the present study was to validate the latter prognostic model for patients undergoing resection of hepatic metastases and to further evaluate the influence of major and extended liver or multivisceral resection (among other selected variables) on the outcome in this special patient collective.

\section{Methods}

\section{Study cohort}

This is a retrospective analysis of patients with stage IV RCC undergoing surgical resection at the Department of General, Visceral and Transplant Surgery, Hannover Medical School, Germany between April 1993 and April 2017.

\section{Inclusion criteria}

Included were all hepatic resections for histologically confirmed metastases of RCC in patients older than 18 years of age. Patients with concomitant extrahepatic disease were included in cases of resectability. No further exclusion criteria were defined. Two patients were lost to follow-up immediately after discharge and were therefore excluded from further survival analysis.

\section{Definition of variables}

Major hepatic surgery was defined as resection of 3 or more liver segments, whereas extended hepatic surgery was defined as resection of 5 or more segments, based on the Brisbane classification [12]. Multivisceral resection was defined as additional resection of infiltrated extrahepatic tissue.

The patients were stratified according to the modified Memorial Sloan-Kettering Score as introduced by Mekhail et al. in 2005 [10]. Poor prognostic factors summarized to a total score for each patient were time from RCC diagnosis until hepatic metastasectomy less than 12 months, hemoglobin levels below lower limit of reference range, LDH more than 1.5 times above the upper limit of reference range, corrected serum calcium above $10 \mathrm{mg} / \mathrm{dl}$, previous radiotherapy, and more than one metastatic site. Patients were stratified into three groups: favorable (0-1 risk factors), intermediate ( 2 risk factors), poor (3 or more risk factors) risk groups [10].

Postoperative complications were classified according to Dindo et al., ranging from grade 0 (no complications), grade I (minor deviations), grade II (significant alterations), grade III (requiring interventions), grade IV (life-threatening), to grade $\mathrm{V}$ (death) [13].

\section{Study endpoints}

Primary study endpoints were disease-free (DFS) and overall survival (OS) upon resection of RCC liver metastases. DFS was defined as time between hepatic metastasectomy and proof of disease recurrence in the course of follow-up, irrespective of the localization (not limited to hepatic recurrence). Secondary endpoints were surgical complications as defined by Dindo et al. and length of hospital and intensive care unit (ICU) stay.

\section{Statistical methods}

The influence of nominal and ordinal variables on binary study endpoints was analyzed with chi-squared test and Fisher's exact test. Median and mean values between groups were compared with the Student's $t$ test or Mann-Whitney $U$ test. Kaplan-Meier analyses including log-rank tests were performed where appropriate. Risk factors for patient survival were initially analyzed with univariable Cox regression analysis. Identification of independent risk factors influencing DFS and OS was achieved by using purposeful selection of variables with a rate of missing values $<10 \%$ and $p$ values in univariable Cox regression of $<0.300$ and consecutive stepwise forward selection.

The collected data was implemented and analyzed using SPSS statistical software (version 26; SPSS Inc.; IBM Corporation, Armonk, NY, USA) and GraphPad Prism (version 8.3.0 for Windows, GraphPad Software, La Jolla, CA, USA).

\section{Results}

\section{Demographics and resection of RCC}

The 40 patients analyzed underwent nephrectomy due to histologically confirmed RCC in curative intent. The median age at the time of nephrectomy was 54 years (35-80). Left and right nephrectomies were equally distributed among the patient cohort; one patient received bilateral nephrectomy. 
Further demographic, clinical, and histopathological data are displayed in Supplemental Table 1 (Online Resource 1).

\section{Hepatic metastasectomy}

The median interval between nephrectomy for RCC and hepatic metastasectomy was 44 months (3.3-278.5). Of note, three patients displayed synchronous (but isolated) hepatic metastases and received partial hepatectomy immediately after nephrectomy.

Fourteen patients were perioperatively diagnosed with multiple metastatic sites including ossary, pulmonary, and further intraabdominal lesions and showed inferior median DFS and OS (9.9 and 23.4 months) when compared with patients without extrahepatic metastases (23.5 and 47.2 months; $p=$ 0.062 and 0.017 , respectively; Fig. 1).

Localization of liver metastases was mainly observed within the right liver lobe $(57.5 \%)$. However, 15 patients $(37.5 \%)$ suffered from bilateral metastases, resulting in a shorter median DFS (8.4 versus 19.7 months; $p=0.562$ ) and OS (24.0 months versus 41.5 months; $p=0.809)$ by trend.

Accordingly, right or right extended hemihepatectomy was most frequent among the resections performed (12 patients $(30.0 \%)$ and 8 patients $(20.0 \%))$.

Multivisceral resections were performed in 8 patients $(20.0 \%)$. These included additional partial pancreatic resections (4 patients) alongside an adrenalectomy (1 patient) and partial resections of the retrohepatic vena cava ( 2 patients), the diaphragm ( 2 patients), and the transverse colon (1 patient) due to tumor invasion. Only one of these patients died in the postoperative course; however, median DFS (8.0 versus 19.7 months; $p=0.060$; Fig. $2 \mathrm{a}$ ) and OS (19.0 versus 41.0 months; $p=0.096$; Fig. 2b) were lower when compared with all other patients.
Median follow-up after hepatic metastasectomy was 37.8 months (0.5-286.5).

The distribution of demographic and clinical variables of the patients undergoing hepatic metastasectomy is presented in Table 1a.

\section{Histopathological results}

Postoperative histopathology of the liver specimens revealed tumor-free resection margins in 37 patients (92.5\%). Although a trend toward better OS was observed, further analysis did not reveal a significant influence of tumor-free resection margins on survival (38.8 versus 6.2 months; $p=0.217$ ).

The histopathological results of the patients undergoing hepatic metastasectomy are summarized in Table 1a.

\section{Postoperative outcome}

Postoperative complications of various extent occurred in 16 patients $(41.0 \%)$, with 9 patients $(23.1 \%)$ suffering from severe complications ( $\geq$ Clavien-Dindo grade III) including two patients dying in the ICU due to post-hepatectomy liver failure and postoperative hemorrhage, respectively.

The incidence of postoperative complications in general and severe complications was not significantly elevated with respect to the extent of hepatic surgery; however, multivisceral resections led to a significant increase of postoperative complications in general $(75.0 \%$ versus $32.3 \%, p=0.028)$ and severe complications $(62.5 \%$ versus $12.9 \%, p=0.003)$.

Tumor recurrence was observed in 19 patients $(67.9 \%)$ resulting in a median DFS of 16.2 months (0.7-265.1; Fig. 3a).

Median OS was 37.8 months (0.5-286.5), whereas 28 patients $(73.7 \%)$ were deceased at the time of analysis (Fig. 3a). Extrahepatic metastases analysis after hepatic metastasectomy in cases of concomitant extrahepatic distant metastases: OS after resection of hepatic metastases in cases of concomitant distant metastases was significantly worse than in patients with isolated liver metastases $\left(p^{*}=0.017\right)$

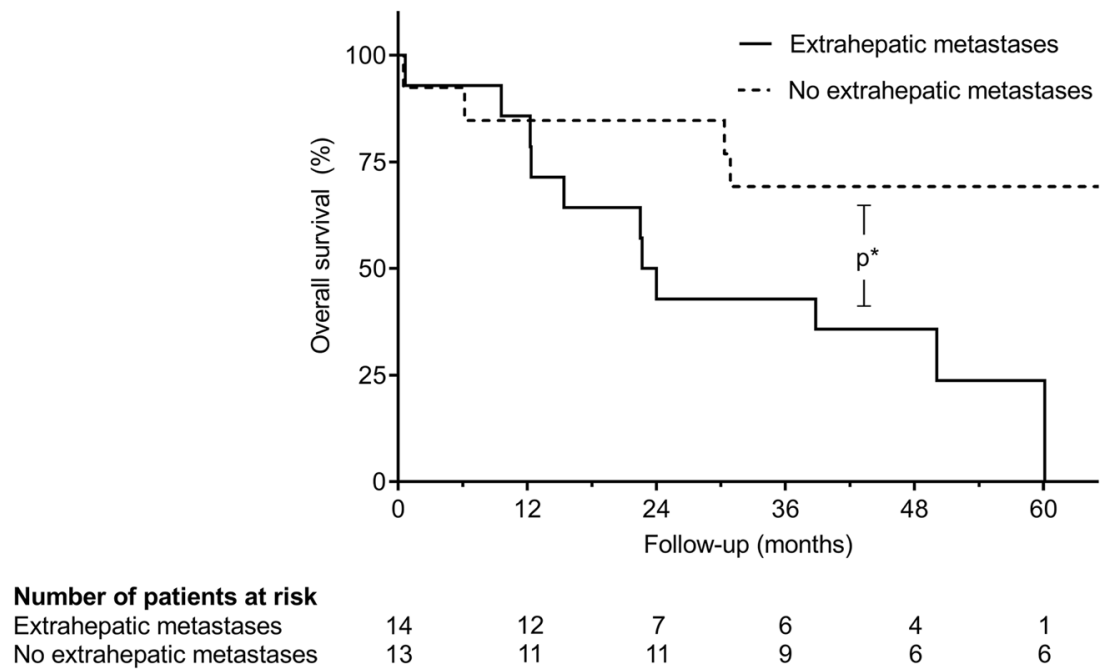

Number of patients at risk No extrahepatic metastases 
a

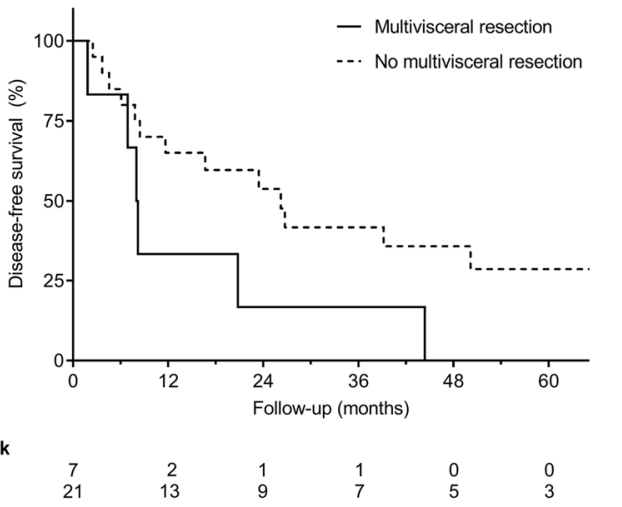

b

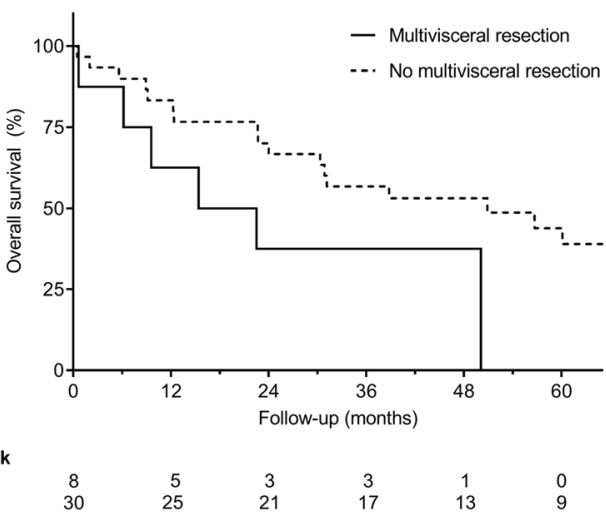

Fig. 2 Kaplan-Meier survival analysis after hepatic metastasectomy in cases of multivisceral resection: patients undergoing simultaneous multivisceral resection showed inferior DFS $(\mathbf{a} p=0.060)$ and OS $(\mathbf{b} p=0.096)$ when compared with patients undergoing isolated liver resection

The prognostic group classification as defined by the modified Memorial Sloan-Kettering Score was associated with inferior survival, but not in a statistically significant manner $(p=0.595$; Fig. 3b).

Table 2 summarizes the postoperative outcome after hepatic metastasectomy.

\section{Approval of sunitinib in Europe}

After introduction of the tyrosine kinase inhibitor sunitinib in Europe in July 2006, 15 patients underwent hepatic metastasectomy. Of these, six patients received targeted therapy either pre- or postoperatively, with sunitinib being initially administered to all patients. Due to severe side effects in two patients, targeted therapy was switched consecutively to other agents, such as pazopanib, temsirolimus, everolimus, and lenvatinib. Of note, none of the patients included in this study received targeted therapy prior to official approval of sunitinib in Europe, neither off-label nor in the course of clinical studies.

Median OS after July 2006 increased significantly (45.2 versus 27.5 months, $p=0.038$; Fig. 4), although patients were significantly older at the time of liver resection (mean age 66.9 versus $57.2, p=0.002$ ).

The extent of hepatic resections by trend was smaller after 2006 , with rates of major and extended hepatic resections at $46.7 \%$ (versus $68.0 \%, p=0.182$ ) and $6.7 \%$ (versus $32.0 \%$, $p=0.063$ ), respectively, also reflected by a significantly shorter mean operation time (165.3 versus 263.3, $p=0.014$ ). Of note, the extent of surgery did not significantly affect DFS or OS in patients undergoing hepatic metastasectomy after introduction of sunitinib.

None of the patients undergoing liver resection after 2006 died in the peri- or postoperative course.

A statistical comparison of selected variables before and after approval of sunitinib is given in Table 3 .

\section{Identification of risk and protective factors for survival}

Univariable Cox regression analysis did not reveal significant risk factors for DFS. However, patients with extrahepatic disease and multivisceral resection showed a trend toward inferior DFS (Table 4a). Multivariable analysis identified multivisceral resection as an independent risk factor (HR, 2.966; 95\% CI, 1.035-8.495; $p=0.043$ ) for DFS (Table $4 \mathrm{~b}$ ).

The presence of extrahepatic metastases, longer operating times, and hepatic metastasectomy before July 2006 were identified as risk factors for OS, whereas a longer interval between nephrectomy and hepatic metastasectomy and the presence of multiple hepatic lesions were identified as protective factors for OS in univariable analysis (Table 1a).

Multivariable analysis identified a longer interval between nephrectomy as an independent protective factor (HR, 0.971; 95\%CI, $0.956-0.987 ; p<0.001)$ and multivisceral resection as an independent risk factor (HR, 9.851; 95\%CI, 2.715$35.737 ; p=0.001$ ) for OS (Table 1b).

\section{Discussion}

Despite several studies on metastasectomy in patients suffering from grade IV RCC, the role of resection of hepatic lesions, especially in times of efficient systemic therapy, remains elusive.

In the current study, we present the largest monocentric database on the matter since Staehler et al. published their patient series in 2010 and, to our knowledge, the first series investigating patient survival following hepatic metastasectomy in the era of targeted therapy [14].

We found a median OS of 37.8 months with 1-, 3-, and 5year survival rates $(78.9 \%, 52.6 \%$, and $38.0 \%$, respectively) in line with results reported in a review by Pikoulis and more recently Pinotti et al. [7, 8]. 
Table 1 (a) Clinical and histopathological variables of the 40 patients undergoing hepatic metastasectomy. (b) Multivariable cox regression analysis for OS

(a)

Variables

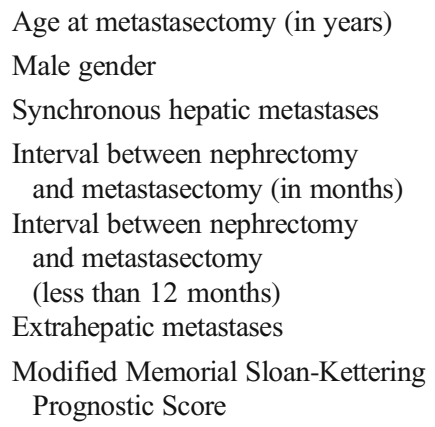

Age at metastasectomy (in years)

Male gender

Synchronous hepatic metastases

Interval between nephrectomy and metastasectomy (in months)

Interval between nephrectomy

and metastasectomy

(less than 12 months)

Extrahepatic metastases

Modified Memorial Sloan-Kettering

Prognostic Score

Localization of hepatic metastases

Type of liver resection

Extent of surgery

Operation time (in minutes)

Portal occlusion (in minutes)

Pathology
Favorable-risk group

Intermediate-risk group

Poor-risk group

Right

Left

Bilateral

Wedge resection

Segmental resection

Right hemihepatectomy

Left extended

Right extended

Ante situ resection

Major hepatectomy

Extended hepatectomy

Multivisceral resection

Multiple hepatic metastases

Number of metastases

Diameter of metastases (in mm)

Positive resection margins (R1)

Safety margins (in $\mathrm{mm}$ )

Before July 2006 (approval of sunitinib in Europe)

(b)

Variables

Interval between nephrectomy and metastasectomy (in months)

Multivisceral resection

$\begin{array}{lll}n(\%) & \text { Mean, median (min.-max.) } & \text { HR; } 95 \% \text { CI; } p \text { value } \\ \text { n.a. } & 60.9,60(38-80) & 0.997 ; 0.960-1.035 ; 0.869 \\ 25(62.5) & \text { n.a. } & 1.483 ; 0.660-3.330 ; 0.340 \\ 3(7.5) & \text { n.a. } & 0.034 ; 0.000-4.989 ; 0.184 \\ \text { n.a. } & 62.3,44(3.3-278.5) & 0.988 ; 0.977-1.000 ; 0.044 \\ 8(20.0) & \text { n.a. } & 1.135 ; 0.420-3.069 ; 0.803 \\ & & \\ 14(50.0) & \text { n.a. } & 3.847 ; 1.184-12.494 ; 0.025 \\ 19(61.3) & \text { n.a. } & 0.853 ; 0.346-2.101 ; 0.729 \\ 8(25.8) & & 0.873 ; 0.315-2.425 ; 0.795 \\ 4(12.9) & & 1.918 ; 0.534-6.888 ; 0.318 \\ 23(57.5) & \text { n.a. } & 1.059 ; 0.479-2.342 ; 0.888 \\ 2(5.0) & & 1.334 ; 0.178-10.015 ; 0.779 \\ 15(37.5) & & 0.905 ; 0.402-2.037 ; 0.809\end{array}$

$6(15.0) \quad$ n.a.

$12(30.0) \quad$ n.a.

$12(30.0)$

$1(2.5)$

$8(20.0)$

$1(2.5)$

$24(60.0) \quad$ n.a.

$0.760 ; 0.346-1.668 ; 0.494$

$9(22.5) \quad$ n.a.

8 (20.0) n.a.

n.a. $\quad 231.5,210(45-670)$

n.a. $\quad 33.1,25(0-220)$

18 (48.6) n.a.

n.a. $\quad 2.3,1(1-12)$

n.a. $\quad 48.8,42.5(1.5-150)$

$3(7.5) \quad$ n.a.

n.a. $\quad 8.6,5(1-35)$

$25(62.5) \quad$ n.a.

$1.027 ; 0.439-2.401 ; 0.952$

$2.223 ; 0.848-5.830 ; 0.104$

$1.005 ; 1.001-1.010 ; 0.010$

$1.011 ; 0.998-1.024 ; 0.101$

$0.413 ; 0.178-0.959 ; 0.040$

$0.726 ; 0.516-1.022 ; 0.066$

$1.001 ; 0.988-1.015 ; 0.885$

$2.452 ; 0.562-10.690 ; 0.223$

$1.016 ; 0.971-1.064 ; 0.487$

$2.718 ; 1.017-7.265 ; 0.046$

$\begin{array}{llr}\text { HR } & 95 \% \mathrm{CI} & p \text { value } \\ 0.971 & 0.956-0.987 & <0.001 \\ 9.851 & 2.715-35.737 & 0.001\end{array}$

Clinical and histopathological variables of the 40 patients undergoing hepatic metastasectomy including the results from univariable Cox regression analysis for OS (HR hazard ratio, $C I$ confidence interval)

Multivariable analysis identified a longer interval between nephrectomy as an independent protective factor and multivisceral resection as an independent risk factor for OS

The published heterogeneous survival (16-142 months) is partially explained by the varying rates of simultaneous extrahepatic disease (0-37\%) and the varying rates of major liver resections in reported patient series (14-85.7\%) [14-17]. In our study, extrahepatic metastases were observed in 14 patients (35.0\%) and led to a significantly worse OS, as was reported by others in the past $[17,18]$. The proportion of patients undergoing major hepatic surgery in our series was also comparatively large $(60.0 \%)$. However, major or extended liver resections $(22.5 \%)$ were not associated with inferior patient outcome, and although multivisceral resection (20.0\%) was identified as an independent significant risk factor for 
a

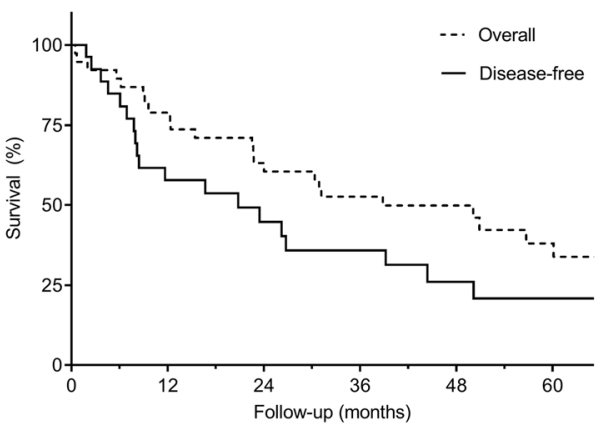

Number of patients at risk

Overall survival
Disease-free survival

$\begin{array}{lllccl}38 & 30 & 24 & 20 & 14 & 9 \\ 28 & 15 & 10 & 8 & 5 & 3\end{array}$

Fig. 3 Kaplan-Meier analysis of DFS and OS after resection of hepatic metastases (a) and of OS according to the modified Memorial SloanKettering (mMSK) prognostic groups (b): survival of patients allocated

inferior DFS and OS, the median OS in these patients was still considerable (19 months). Of note, multivisceral resections included pancreatic metastases since beneficiary survival has been shown in cases of pancreatic metastasectomy by others in the past $[19,20]$. b

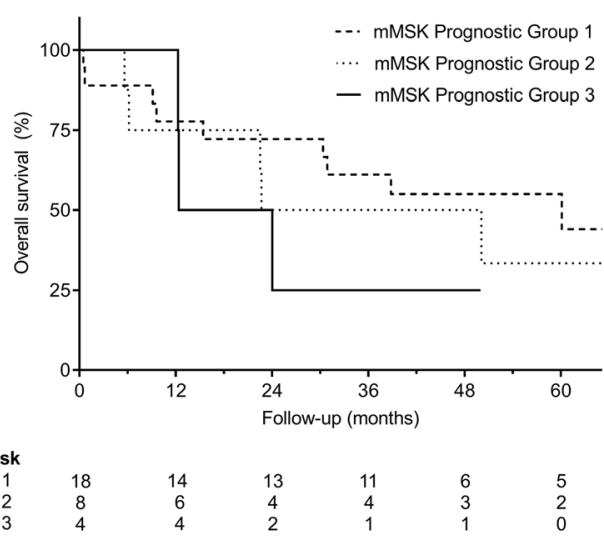

mMSK Prognostic Group 1

mMSK Prognostic Group 2

to the poor prognostic group (3) was worse than in patients allocated to the favorable (1) and intermediate prognostic groups (2); however, without statistical significance $(p=0.595)$

Even though high-volume oncologic liver surgery is performing at our institution, our observation period was long, spanning three decades due to the low incidence of resectable RCC liver metastases, like in most reports on the matter [7, 8, 21]. Since surgical protocols were refined and, even more
Table 2 Postoperative outcome after hepatic metastasectomy

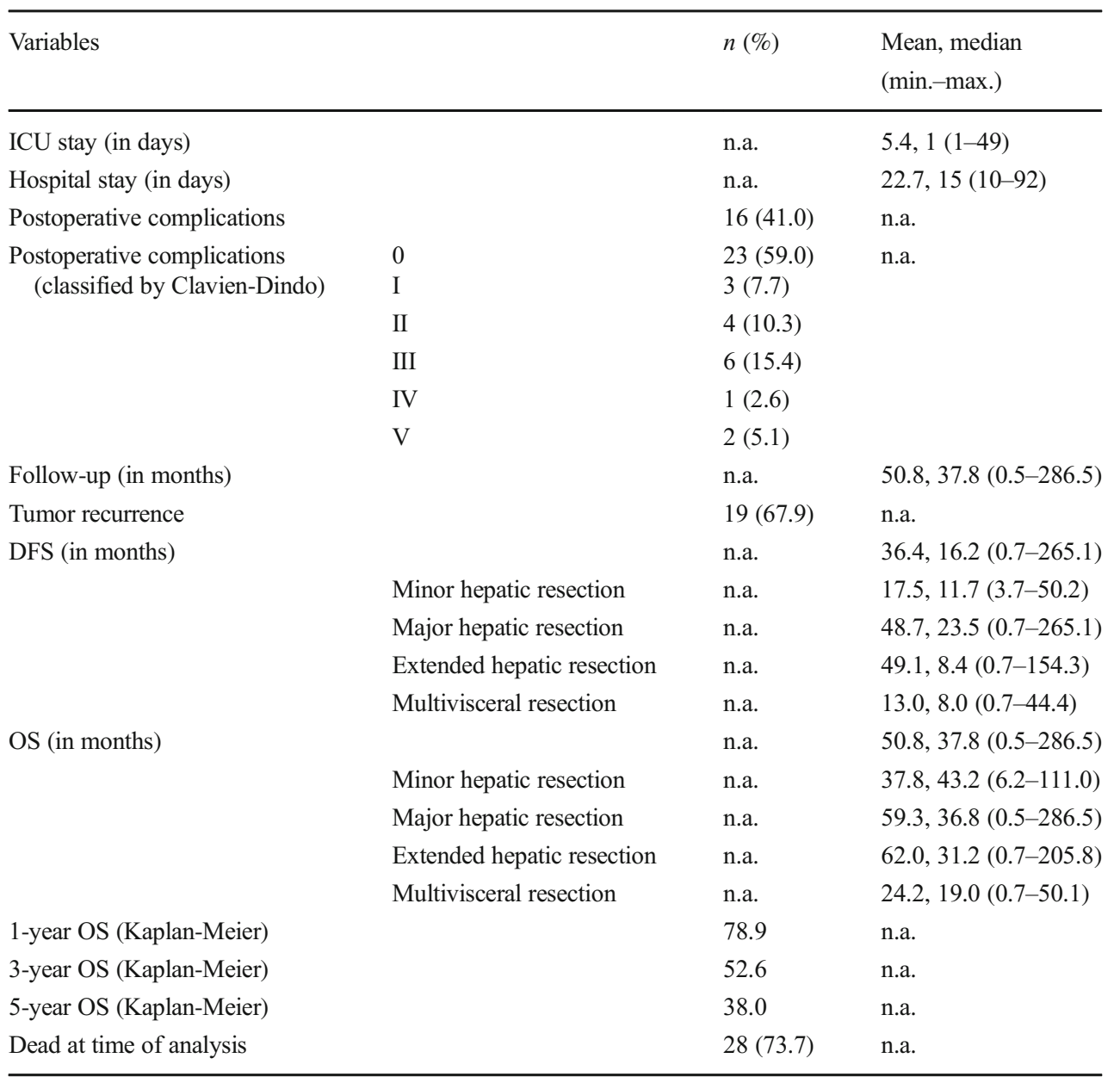


Fig. 4 Kaplan-Meier analysis of OS after resection of hepatic metastases before and after approval of sunitinib: survival after hepatic metastasectomy before approval of sunitinib in July 2006 was significantly worse than in patients after July 2006 $\left(p^{*}=0.038\right)$

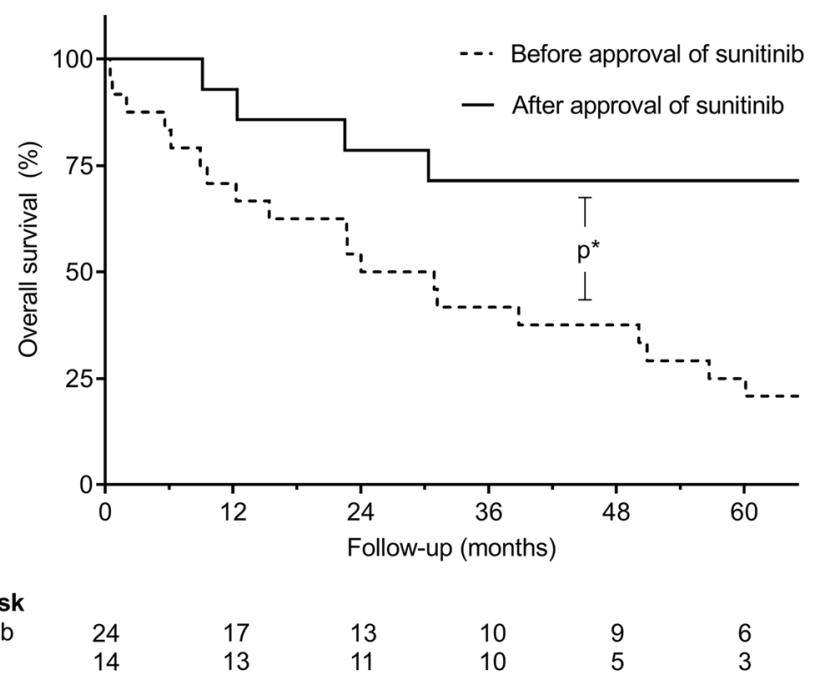

Number of patients at risk Before approval of sunitinib After approval of sunitinib significant factor for better survival, in patients undergoing hepatic metastasectomy after July 2006 (48.0 versus 25.9 months) [15-18, 27, 28]. Furthermore, a tendency toward lesser extended hepatic surgery, reflected by significantly shorter operating times and lower rates of major and extended liver resections $(46.7 \%$ versus $68.0 \%$ ), since the introduction of targeted therapy was found. Despite these observations, we cannot prove that solely the option of targeted therapy led to less (aggressive) hepatic surgery in our patients, due to the retrospective nature of the study. Other developments in the treatment of hepatic malignancies, such as the introduction and widespread use of less invasive technologies, including radiofrequency ablation, selective internal radiation therapy, or transarterial chemoembolization, also have to be discussed as an explanation for our findings.

We analyzed further factors supposedly influencing postoperative outcome. These included positive resection margins which were associated with a higher hazard ratio but did not significantly influence patient survival, as opposed to several reports in the past [27-30]. An explanation could be the small number of only three patients showing positive resection margins, reflecting an aggressive approach and resulting in a comparatively high rate of major and extended hepatic and multivisceral resections.

As summarized by the review from Pikoulis et al., neither the number, the size, nor the laterality of liver metastases had an impact on patient outcome [7].

The modified Memorial Sloan-Kettering Prognostic Factors Model for patients with metastasized RCC could not be validated in our patient series, despite a trend toward superior survival for the favorable-risk group. This could be the result of a comparatively small sample size, with only four patients allocated to the poor-risk group. We suggest that larger patient series, preferably in multi-center studies, should be analyzed in the future to clarify the role of the abovementioned prognostic model in patients with RCC liver metastases.

Limitations of the present study are the retrospective nature combined with a heterogeneous patient selection and missing mary nephrectomy and liver resection, known as an independent 
Table 3 Comparison of selected variables at the time of hepatic metastasectomy and postoperative outcome before and after approval of sunitinib in 2006

\begin{tabular}{|c|c|c|c|c|c|}
\hline \multicolumn{3}{|l|}{ Variables } & \multirow{2}{*}{$\begin{array}{l}\text { Before July } 2006 \\
\text { Mean, median } \\
(\min .- \text { max.) or } n(\%)\end{array}$} & \multirow{2}{*}{$\begin{array}{l}\text { After July } 2006 \\
\text { Mean, median } \\
(\text { min.-max.) or } n(\%)\end{array}$} & \multirow{2}{*}{$\frac{p \text { value }}{0.002}$} \\
\hline Age at metastasectomy (in years) & & & & & \\
\hline Male gender & & & $17(68.0)$ & $8(53.3)$ & 0.354 \\
\hline Synchronous hepatic metastases & & & $1(4.0)$ & $2(13.3)$ & 0.278 \\
\hline $\begin{array}{l}\text { Interval between nephrectomy } \\
\text { and metastasectomy (in months) }\end{array}$ & & & $50.6,25.9(3.3-216.9)$ & $85.7,48.0(6.3-278.5)$ & 0.159 \\
\hline \multirow{2}{*}{$\begin{array}{l}\text { Modified Memorial Sloan-Kettering } \\
\text { Prognostic Score }\end{array}$} & Favorable-risk group & & $9(56.3)$ & $10(66.7)$ & \multirow[t]{2}{*}{0.771} \\
\hline & $\begin{array}{l}\text { Intermediate-risk group } \\
\text { Poor-risk group }\end{array}$ & & $\begin{array}{l}5(31.3) \\
2(12.5)\end{array}$ & $\begin{array}{l}3(20.0) \\
2(13.3)\end{array}$ & \\
\hline \multirow[t]{2}{*}{ Localization of hepatic metastases } & $\begin{array}{l}\text { Right } \\
\text { Left }\end{array}$ & & $\begin{array}{l}12(48.0) \\
1(4.0)\end{array}$ & $\begin{array}{l}11(73.3) \\
1(6.7)\end{array}$ & \multirow[t]{2}{*}{0.208} \\
\hline & Bilateral & & $12(48.0)$ & $3(20.0)$ & \\
\hline \multirow[t]{5}{*}{ Type of liver resection } & $\begin{array}{l}\text { Wedge resection } \\
\text { Segmental resection }\end{array}$ & & $\begin{array}{l}1(4.0) \\
8(32.0)\end{array}$ & $\begin{array}{l}5(33.3) \\
4(26.7)\end{array}$ & \multirow[t]{5}{*}{0.148} \\
\hline & Right hemihepatectomy & & $7(28.0)$ & $5(33.3)$ & \\
\hline & Left extended & & $1(4.0)$ & $0(0.0)$ & \\
\hline & Right extended & & $7(28.0)$ & $1(6.7)$ & \\
\hline & Ante situ resection & & $1(4.0)$ & $0(0.0)$ & \\
\hline \multirow[t]{3}{*}{ Extent of surgery } & Major hepatectomy & & $17(68.0)$ & $7(46.7)$ & 0.182 \\
\hline & Extended hepatectomy & & $8(32.0)$ & $1(6.7)$ & 0.063 \\
\hline & Multivisceral resection & & $5(20.0)$ & $3(20.0)$ & 1.000 \\
\hline Operation time (in minutes) & & & $263.3,250.0(45-670)$ & $165.3,145.5(104-344)$ & 0.014 \\
\hline Portal occlusion (in minutes) & & & $41.6,29.5(0-220)$ & $16.1,10.0(0-89)$ & 0.125 \\
\hline \multirow[t]{5}{*}{ Pathology } & \multicolumn{2}{|l|}{ Multiple hepatic metastases } & $10(40.0)$ & $8(53.3)$ & 0.420 \\
\hline & \multicolumn{2}{|l|}{ Number of metastases } & $1.8,1(1-5)$ & $3.3,2(1-12)$ & 0.388 \\
\hline & \multicolumn{2}{|l|}{ Diameter of metastases (in mm) } & $53.1,42.5(1.5-150)$ & $41.5,33.5(7-120)$ & 0.327 \\
\hline & \multicolumn{2}{|l|}{ Positive resection margins (R1) } & $2(8.0)$ & $1(6.7)$ & 0.877 \\
\hline & \multicolumn{2}{|l|}{ Safety margins (in mm) } & $11.2,8(1-35)$ & $4.1,3(1-12)$ & 0.085 \\
\hline \multirow[t]{13}{*}{ Postoperative outcome } & ICU stay (in days) & & $6.2,1(1-49)$ & $3.9,1(1-32)$ & 0.467 \\
\hline & Hospital stay (in days) & & $24.1,15(10-92)$ & $21.6,15(10-60)$ & 0.970 \\
\hline & Postoperative complications & & $10(40.0)$ & $6(42.9)$ & 0.862 \\
\hline & \multirow[t]{5}{*}{$\begin{array}{l}\text { Postoperative complications } \\
\quad \text { (classified by Clavien-Dindo) }\end{array}$} & $\begin{array}{l}0 \\
\mathrm{I}\end{array}$ & $\begin{array}{l}15(60.0) \\
1(4.0)\end{array}$ & $\begin{array}{l}8(57.1) \\
2(14.3)\end{array}$ & \multirow[t]{5}{*}{0.601} \\
\hline & & II & $3(12.0)$ & $1(7.1)$ & \\
\hline & & III & $3(12.0)$ & $3(21.4)$ & \\
\hline & & IV & $1(4.0)$ & $0(0.0)$ & \\
\hline & & $\mathrm{V}$ & $2(8.0)$ & $0(0.0)$ & \\
\hline & \multicolumn{2}{|l|}{ Follow-up (in months) } & $53.2,27.5(0.5-286.5)$ & $46.7,45.2(9.1-111)$ & 0.402 \\
\hline & \multicolumn{2}{|l|}{ Tumor recurrence } & $9(64.3)$ & $10(71.4)$ & 0.686 \\
\hline & \multicolumn{2}{|l|}{ DFS (in months) } & $54.9,20.1(0.7-265.1)$ & $18.0,13.7(1.8-58.3)$ & 0.303 \\
\hline & \multicolumn{2}{|l|}{ OS (in months) } & $53.2,27.5(0.5-286.5)$ & $46.7,45.2(9.1-111)$ & 0.038 \\
\hline & \multicolumn{2}{|l|}{ Dead at time of analysis } & $23(95.8)$ & $5(35.7)$ & $<0.001$ \\
\hline
\end{tabular}

control groups, diminishing the statistical power of our observations. Of note, collection of complete clinical and histopathological data of patients undergoing hepatic metastasectomy, especially in the early observation period, was partially not possible since patients, relatives, and even physicians in charge were deceased at the time of analysis. We believe, however, that it is essential to report on patient series with a comparatively rare surgical indication and that our findings could contribute to facilitating optimal patient selection and subsequent outcome in the future of a rapidly evolving therapeutic landscape [31]. 
Table 4 (a) Univariable Cox regression analysis for DFS. (b) Multivariable Cox regression analysis for DFS (a)

\begin{tabular}{|c|c|c|c|c|}
\hline \multicolumn{2}{|l|}{ Variables } & HR & $95 \% \mathrm{CI}$ & $p$ value \\
\hline \multicolumn{2}{|c|}{ Age at metastasectomy (in years) } & 0.993 & $0.948-1.040$ & 0.768 \\
\hline \multicolumn{2}{|l|}{ Male gender } & 1.846 & $0.698-4.877$ & 0.216 \\
\hline \multicolumn{2}{|c|}{$\begin{array}{l}\text { Interval between nephrectomy and metastasectomy } \\
\text { (in months) }\end{array}$} & 0.997 & $0.990-1.005$ & 0.512 \\
\hline \multicolumn{2}{|c|}{ Extrahepatic metastases } & 2.520 & $0.924-6.872$ & 0.071 \\
\hline \multicolumn{2}{|c|}{ Bilateral localization of hepatic metastases } & 0.750 & $0.282-1.992$ & 0.564 \\
\hline \multirow[t]{3}{*}{ Extent of surgery } & Major hepatectomy & 0.543 & $0.216-1.363$ & 0.194 \\
\hline & Extended resection & 0.547 & $0.158-1.889$ & 0.340 \\
\hline & Multivisceral resection & 2.512 & $0.931-6.782$ & 0.069 \\
\hline \multicolumn{2}{|c|}{ Operation time (in minutes) } & 1.001 & $0.995-1.007$ & 0.782 \\
\hline \multicolumn{2}{|c|}{ Portal occlusion (in minutes) } & 0.971 & $0.941-1.002$ & 0.067 \\
\hline \multirow[t]{5}{*}{ Pathology } & Multiple hepatic metastases & 0.947 & $0.326-2.748$ & 0.920 \\
\hline & Number of metastases & 0.905 & $0.745-1.099$ & 0.312 \\
\hline & Diameter of metastases (in mm) & 0.996 & $0.979-1.014$ & 0.664 \\
\hline & Positive resection margins & 1.009 & $0.132-7.706$ & 0.993 \\
\hline & Safety margins (in mm) & 1.016 & $0.955-1.081$ & 0.608 \\
\hline \multicolumn{2}{|c|}{ Before July 2006 (introduction of sunitinib in Europe) } & 0.618 & $0.245-1.557$ & 0.307 \\
\hline \multicolumn{5}{|l|}{ (b) } \\
\hline \multicolumn{2}{|l|}{ Variables } & $\mathrm{HR}$ & $95 \% \mathrm{CI}$ & $p$ value \\
\hline \multicolumn{2}{|c|}{ Multivisceral resection } & 2.966 & $1.035-8.495$ & 0.043 \\
\hline
\end{tabular}

Univariable Cox regression analysis did not reveal significant risk factors for DFS; however, patients with extrahepatic disease and multivisceral resection showed a trend toward inferior DFS

Multivisceral resection was identified as independent significant risk factor for DFS

\section{Conclusion}

Despite the introduction of novel targeted therapies, surgical concepts still remain the only chance for long-term survival or cure in selected patients. Hepatic metastasectomy on patients with RCC stage IV disease can be performed safely and allows long-term survival, albeit with an increased risk of postoperative complications especially following multivisceral surgery. It will be crucial to define the role of hepatic metastasectomy with a focus on patients suffering from an extended metastatic disease in the context of future multimodal therapy strategies.

Author's contributions Study conception and design: Oliver Beetz, Rabea Söffker, Moritz Kleine. Acquisition of data: Oliver Beetz, Rabea Söffker, Moritz Kleine. Analysis and interpretation of data: Oliver Beetz, Felix Oldhafer, Moritz Kleine. Drafting of manuscript: Oliver Beetz, Sebastian Cammann, Felix Oldhafer, Moritz Kleine. Critical revision of manuscript: Florian W. R. Vondran, Florian Imkamp, Jürgen Klempnauer

Funding Information Open access funding provided by Projekt DEAL.

\section{Compliance with ethical standards}

Conflict of interest The authors declare that they have no conflict of interest.

Informed consent and ethics approval Patients provided informed consent that their data may be used for scientific purposes at the time of hospital admission which is the general policy of our institution. The ethical committee of Hannover Medical School stated that no further approval for retrospective analyses is needed. Patient records and patient data were anonymized and de-identified prior to analysis.

Open Access This article is licensed under a Creative Commons Attribution 4.0 International License, which permits use, sharing, adaptation, distribution and reproduction in any medium or format, as long as you give appropriate credit to the original author(s) and the source, provide a link to the Creative Commons licence, and indicate if changes were made. The images or other third party material in this article are included in the article's Creative Commons licence, unless indicated otherwise in a credit line to the material. If material is not included in the article's Creative Commons licence and your intended use is not permitted by statutory regulation or exceeds the permitted use, you will need to obtain permission directly from the copyright holder. To view a copy of this licence, visit http://creativecommons.org/licenses/by/4.0/.

\section{References}

1. Capitanio U, Bensalah K, Bex A, Boorjian SA, Bray F, Coleman J, Gore JL, Sun M, Wood C, Russo P (2019) Epidemiology of renal cell carcinoma. Eur Urol 75:74-84. https://doi.org/10.1016/j.eururo.2018. 08.036

2. Hamada S, Ito K, Kuroda K, Sato A, Asakuma J, Horiguchi A, Seguchi K, Asano T (2015) Clinical characteristics and prognosis of patients with renal cell carcinoma and liver metastasis. Mol Clin Oncol 3:63-68. https://doi.org/10.3892/mco.2014.432 
3. Bianchi M, Sun M, Jeldres C, Shariat SF, Trinh QD, Briganti A, Tian Z, Schmitges J, Graefen M, Perrotte P, Menon M, Montorsi F, Karakiewicz PI (2012) Distribution of metastatic sites in renal cell carcinoma: a population-based analysis. Ann Oncol 23:973-980. https://doi.org/10.1093/annonc/mdr362

4. Jakubowski CD, Vertosick EA, Untch BR, Sjoberg D, Wei E, Palmer FL, Patel SG, Downey RJ, Strong VE, Russo P (2016) Complete metastasectomy for renal cell carcinoma: comparison of five solid organ sites. J Surg Oncol 114:375-379. https://doi.org/10.1002/jso.24327

5. You D, Lee C, Jeong IG, Song C, Lee JL, Hong B, Hong JH, Ahn H, Kim CS (2016) Impact of metastasectomy on prognosis in patients treated with targeted therapy for metastatic renal cell carcinoma. J Cancer Res Clin Oncol 142:2331-2338. https://doi.org/10. 1007/s00432-016-2217-1

6. Grimes NG, Devlin JM, Dunne DFJ, Jones RP, Poston GJ, Fenwick SW, Malik HZ (2014) A systematic review of the role of hepatectomy in the management of metastatic renal cell carcinoma. Eur J Surg Oncol 40:1622-1628. https://doi.org/10.1016/j.ejso.2014.08.472

7. Pikoulis E, Margonis GA, Antoniou E (2016) Surgical management of renal cell cancer liver metastases. Scand J Surg 105:263-268. https://doi.org/10.1177/1457496916630644

8. Pinotti E, Montuori M, Giani A, Uggeri F, Garancini M, Gianotti L, Romano F (2019) Surgical treatment of liver metastases from kidney cancer: a systematic review. ANZ J Surg 89:32-37. https://doi. org/10.1111/ans. 15000

9. Motzer RJ, Mazumdar M, Bacik J, Berg W, Amsterdam A, Ferrara J (1999) Survival and prognostic stratification of 670 patients with advanced renal cell carcinoma. J Clin Oncol 17:2530-2540. https:// doi.org/10.1200/JCO.1999.17.8.2530

10. Mekhail TM, Abou-Jawde RM, Boumerhi G, Malhi S, Wood L, Elson P, Bukowski R (2005) Validation and extension of the Memorial SloanKettering prognostic factors model for survival in patients with previously untreated metastatic renal cell carcinoma. J Clin Oncol 23:832841. https://doi.org/10.1200/JCO.2005.05.179

11. Zerbi A, Ortolano E, Balzano G, Borri A, Beneduce AA, di Carlo V (2008) Pancreatic metastasis from renal cell carcinoma: which patients benefit from surgical resection? Ann Surg Oncol 15:11611168. https://doi.org/10.1245/s10434-007-9782-0

12. Strasberg SM (2005) Nomenclature of hepatic anatomy and resections: a review of the Brisbane 2000 system. J Hepato-Biliary-Pancreat Surg 12:351-355. https://doi.org/10.1007/s00534-005-0999-7

13. Dindo D, Demartines N, Clavien PA (2004) Classification of surgical complications: a new proposal with evaluation in a cohort of 6336 patients and results of a survey. Ann Surg 240:205-213

14. Staehler MD, Kruse J, Haseke N, Stadler T, Roosen A, Karl A, Stief CG, Jauch KW, Bruns CJ (2010) Liver resection for metastatic disease prolongs survival in renal cell carcinoma: 12-year results from a retrospective comparative analysis. World J Urol 28:543547. https://doi.org/10.1007/s00345-010-0560-4

15. Aloia TA, Adam R, Azoulay D, Bismuth H, Castaing D (2006) Outcome following hepatic resection of metastatic renal tumors: the Paul Brousse Hospital experience. HPB 8:100-105. https:// doi.org/10.1080/13651820500496266

16. Alves A, Adam R, Majno P, Delvart V, Azoulay D, Castaing D, Bismuth $\mathrm{H}$ (2003) Hepatic resection for metastatic renal tumors: is it worthwhile? Ann Surg Oncol 10:705-710

17. Hatzaras I, Gleisner AL, Pulitano C, Sandroussi C, Hirose K, Hyder O, Wolfgang CL, Aldrighetti L, Crawford M, Choti MA, Pawlik TM (2012) A multi-institution analysis of outcomes of liverdirected surgery for metastatic renal cell cancer. HPB 14:532538. https://doi.org/10.1111/j.1477-2574.2012.00495.x

18. Adam R, Chiche L, Aloia T, Elias D, Salmon R, Rivoire M, Jaeck D, Saric J, le Treut YP, Belghiti J, Mantion G, Mentha G, Association Française de Chirurgie (2006) Hepatic resection for noncolorectal nonendocrine liver metastases: analysis of 1,452 patients and development of a prognostic model. Ann Surg 244: 524-535. https://doi.org/10.1097/01.sla.0000239036.46827.5f

19. Yuasa T, Inoshita N, Saiura A, Yamamoto S, Urakami S, Masuda H, Fujii Y, Fukui I, Ishikawa Y, Yonese J (2015) Clinical outcome of patients with pancreatic metastases from renal cell cancer. BMC Cancer 15:46-46. https://doi.org/10.1186/s12885-015-1050-2

20. Alzahrani MA, Schmulewitz N, Grewal S, Lucas FV, Turner KO, McKenzie J, Sussman JJ, Ahmad SA (2012) Metastases to the pancreas: the experience of a high volume center and a review of the literature. J Surg Oncol 105:156-161. https://doi.org/10.1002/ jso. 22009

21. Lehner F, Ramackers W, Bektas H et al (2009) Liver resection for non-colorectal, non-neuroendocrine liver metastases-is hepatic resection justified as part of the oncosurgical treatment? Zentralblatt fur Chir - Zeitschrift fur Allg Visz und Gefasschirurgie 134:430 436. https://doi.org/10.1055/s-0029-1224601

22. Motzer RJ, Hutson TE, Tomczak P et al (2009) Overall survival and updated results for sunitinib compared with interferon alfa in patients with metastatic renal cell carcinoma. J Clin Oncol 27:3584 3590. https://doi.org/10.1200/JCO.2008.20.1293

23. Escudier B, Eisen T, Stadler WM, Szczylik C, Oudard S, Staehler M, Negrier S, Chevreau C, Desai AA, Rolland F, Demkow T, Hutson TE, Gore M, Anderson S, Hofilena G, Shan M, Pena C, Lathia C, Bukowski RM (2009) Sorafenib for treatment of renal cell carcinoma: final efficacy and safety results of the phase III treatment approaches in renal cancer global evaluation trial. J Clin Oncol 27:3312-3318. https://doi.org/10.1200/JCO.2008.19.5511

24. Gill DM, Hahn AW, Hale P, Maughan BL (2018) Overview of current and future first-line systemic therapy for metastatic clear cell renal cell carcinoma. Curr Treat Options in Oncol 19:6. https://doi.org/10.1007/s11864-018-0517-1

25. McKay RR, Kroeger N, Xie W, Lee JL, Knox JJ, Bjarnason GA, MacKenzie M, Wood L, Srinivas S, Vaishampayan UN, Rha SY, Pal SK, Donskov F, Tantravahi SK, Rini BI, Heng DY, Choueiri TK (2014) Impact of bone and liver metastases on patients with renal cell carcinoma treated with targeted therapy. Eur Urol 65:577-584. https://doi.org/10.1016/j.eururo.2013.08.012

26. Ouzaid I, Capitanio U, Staehler M, Wood CG, Leibovich BC, Ljungberg B, van Poppel H, Bensalah K, Young Academic Urologists Kidney Cancer Working Group of the European Association of Urology (2019) Surgical metastasectomy in renal cell carcinoma: a systematic review. Eur Urol Oncol 2:141-149. https://doi.org/10.1016/j.euo.2018.08.028

27. Ruys AT, Tanis PJ, Iris ND et al (2011) Surgical treatment of renal cell cancer liver metastases: a population-based study. Ann Surg Oncol 18:1932-1938. https://doi.org/10.1245/s10434-010-1526-x

28. Thelen A, Jonas S, Benckert C, Lopez-Hänninen E, Rudolph B, Neumann U, Neuhaus $P$ (2007) Liver resection for metastases from renal cell carcinoma. World J Surg 31:802-807. https://doi.org/10. 1007/s00268-007-0685-9

29. Lang H, Nussbaum KT, Weimann A, Raab R (1999) Liver resection for non-colorectal, non-neuroendocrine hepatic metastases. Chirurg 70:439-446

30. Marudanayagam R, Sandhu B, Perera MTPR, Taniere P, Coldham C, Bramhall S, Mayer D, Buckels J, Mirza D (2011) Hepatic resection for non-colorectal, non-neuroendocrine, non-sarcoma metastasis: a single-centre experience. HPB (Oxford) 13:286-292. https:// doi.org/10.1111/j.1477-2574.2010.00285.x

31. Salgia NJ, Dara Y, Bergerot P, Salgia M, Pal SK (2019) The changing landscape of management of metastatic renal cell carcinoma: current treatment options and future directions. Curr Treat Options in Oncol 20:41. https://doi.org/10.1007/s11864-019-0638-1

Publisher's note Springer Nature remains neutral with regard to jurisdictional claims in published maps and institutional affiliations. 